\title{
DETERMINANTS OF FARMERS' ADOPTION OF AGROFORESTRY TECHNOLOGY IN IBARAPA AREA OF OYO STATE, NIGERIA
}

\author{
Awe, F., Oguntoye, T.O. and Olatunji, B.T. \\ Forest Economics and Extension Department, Forestry Research Institute of Nigeria, P.M.B. \\ 5054, Jericho Hills, Ibadan, Oyo State, Nigeria.
}

Corresponding author's mail: femray4real@yahoo.com

\begin{abstract}
This study examined the various forms of agroforestry technologies adopted by the farmers as well as assessed the factors influencing the adoption of agroforestry technologies among farmers in the study area. A multi-stage sampling technique was used to select the respondents from the study area. Both descriptive statistics such as frequencies and percentages as well as inferential statistics such as Logistic Regression model were used in the study. From the study, it was discovered that adopters of agroforestry technology accounts for $42.47 \%$, while non-adopters accounted for $57.53 \%$ of the sampled respondents. The result further shows the different forms of agroforestry practices adopted by the farmers in the study area which includes boundary planting, multipurpose trees/shrubs, wind breaks and live fencing. The result of the analysis of the factors that influence the adoption of agroforestry technologies among farmers from the logistic regression analysis revealed that access to extension services, age, education, farming experience, farm size and gender were positive and significant factors in determining the adoption of agroforestry technologies among the farmers.
\end{abstract}

Keywords: Agroforestry, Logistic Regression, boundary planting, live fencing, Ibarapa https://dx.doi.org/10.4314/jafs.v19i1.14

\section{INTRODUCTION}

Majority of Nigeria's population live in the rural areas and the most of these people depend mainly on agriculture for their livelihoods (Odurukwe, 2004). This notwithstanding, rural farmers face myriad of challenges including low productivity, high dependence on rain-fed agriculture, insecurity of the traditional land tenure system and environmental degradation, resulting from unsustainable agricultural practices. Owing to these challenges, rural farmers face low productivity which has led to high incidence of poverty among the farmers (Opio, 2001). Part of the solution to address low land productivity, especially among rural farmers, is to embrace new farming techniques called agroforestry technologies. These technologies have been tried in research stations in Nigeria since 1980 and also on farms since 1984 in collaboration with farmers (Franzel et al., 2002). Agroforestry technologies offer an 

alternative solution to resource-constrained smallholder farmers, who in the absence of inorganic fertilizers would otherwise grow crops without addressing nutrient requirements and harvest little or nothing for storage.

Agroforestry has been defined as a land use system in which woody perennials are grown with food crops and/or livestock leading to many beneficial, ecological and economic interactions between trees and non-trees components. The International Council for Research in Agroforestry (ICRAF) now World Agroforestry Centre defined agroforestry as a `dynamic ecologically based natural resources management system that through interactions of trees on farm and in the agricultural landscape diversifies and sustains production, enhancing social, economic and environmental benefits for land users at all levels. Dawson et al (2013) observed that more than 1.3 billion people worldwide practice the system which ranges from open packed assemblages to dense imitation of tropical rainforests such as home gardens to planted mixture of only few species to trees planted in hedges or on boundaries of field and farms with different levels of human involvement in various management. They observed that agroforestry supports food and nutrition through the direct provision of food, by raising farmers' income and providing fuel for cooking and through various ecosystem services. Garrity and Stapleton (2011) noted that agroforestry is one of mankind best hopes to create a climate-smart agriculture, increase food security, alleviate rural poverty and achieve a truly sustainable development. Kio (2001) stated that a wider application of agroforestry system will reduce the necessity to cut down additional forest and encourage a fuller use of natural forest ecosystems for the products and services which they only can provide. This, he said, is an addition to its potential to increase organic matters of the soil leading to a more efficient nutrient cycling and improvement of the soil physical conditions among others.

Agroforestry technologies range from traditional to recent practices such as Taungya, home gardens, improved fallows, multipurpose trees, plantation-crop combinations, silvopasture, shelterbelts and windbreaks, and alley cropping (Alavalapati and Mercer, 2004). Agroforestry technologies have been proven to have the potential for improving productivity and the livelihoods of rural farmers (Garrity, 2006; Swallow et al. 2009). However, efforts to promote the practice of agroforestry among farmers in Nigeria have not yielded the desired result, despite the vast potential of agroforestry technologies in the country. Therefore, the objective of this study is to identify different forms of agroforestry technologies adopted by the farmers in the study area as well as explore the factors that influence the adoption of agroforestry technologies in Ibarapa area of Oyo State. The region was selected for the study 
Journal of Agriculture and Food Sciences

Volume 19 Number 1, April 2021 pp 189-200

Awe, F., Oguntoye, T.O. and Olatunji, B.T. owing to its agrarian nature and great prospect for agricultural development in Oyo State and agroforestry practices.

\section{MATERIALS AND METHODS}

This study was conducted in Ibarapa Area, Southwest, and Nigeria. The Ibarapa people are a group of Yoruba people located in the South-western part of Nigeria (Abimbola, 2006). The name of the group is derived from a local cultivar of the melon plant, known locally as Egusi Ibara, which was historically acknowledged by neighbouring peoples such as the Egbas, Ibadans and Oyos to be extensively cultivated in the area. The Ibarapa area falls within latitudes $7^{0} .15^{1} \mathrm{~N}$ and $7^{0} .55^{1} \mathrm{~N}$ and longitudes $3^{0} \mathrm{E}$ and $3^{0} .30^{1} \mathrm{E}$. It is located approximately $100 \mathrm{Km}$ north of the coast of Lagos, and about $95 \mathrm{Km}$ west of the Oyo state capital and neighbouring city of Ibadan. They border Yorubas of Onko extraction to the North (Iwajowa, Kajola and Iseyin LGAs) and Yorubas of Oyo extraction to the East (Ibadan). The Yewas or Egbados to the West, and the Egbas to the South (https://en.wikipedia.org/wiki/Ibarapa_people)

The area is approximately $2,496 \mathrm{~km}^{2}$ in geographical size, and consists mostly of rolling savannah with forests situated along the southern border and in isolated patches along river courses such as the Ogun. The natural vegetation was originally rainforest but that has been mostly transformed into derived type savannah as a result of several centuries of slashes and burn agricultural practices (Abimbola, 2006). Most of the land lies at elevations ranging between 120 and 200 meters above sea level, but rocky inselbergs and outcrops can be seen rising to 340 meters (approximately 1,115 ft).

Ibarapa land is traditionally made up of 7 principal towns known as the Ibarapa-Meje (Ibarapa Seven), and their surrounding villages and farmsteads. These towns include Igangan, Eruwa, Aiyete, Tapa, Idere, Igbo-Ora, and Lanlate. Tapa and Aiyete are in Ibarapa North Local Government Area, Igangan, Idere and Igbo-Ora are in Ibarapa Central, while Lanlate and Eruwaare located in Ibarapa East Local Government. The three local governments were created by the federal government of Nigeria authorities in 1996 when Ibarapa East was carved out from the old Ibarapa Local Government while Ibarapa Central and North were carved out of the former Ifeloju Local Government Area. 
A multistage sampling technique was used for the study. The first stage involved the purposive selection of the region due to its significance to food production of the state, as some of the food produced in the state comes from farmers in the region. The second stage involved random selection of two communities from each of the Local Government Areas (LGAs) that make up the region, making a total of six communities in all. The third stage is the random selection of twenty-five respondents from each of the selected communities, making a total of one hundred and fifty (150) respondents. However, only one hundred and forty-six (146) copies were retrieved and used for the analysis. Data was collected through the use of questionnaire, focus group discussion and key informant interview methods. Focus Group Discussion (FGD) and Key Informant Interview Techniques were an important approach to get opinions from groups of people and were critical in terms of capturing information not captured through the use of questionnaire.

\section{Method of Data Analysis}

In this study, binary logistic regression model was used to determine the factors affecting the adoption of agroforestry technologies among farmers in the study area. Binary logistic regression model is a statistical technique used to calculate the relationship between a dichotomous dependent variable and independent variables.

The binary logit regression estimates the possibility that a feature is present, or otherwise given the values of extraneous variables. If probability of adopting agroforestry practices is

given by $\mathrm{Y}$, then that for not adopting is given by $1-\mathrm{Y}$. The ratio referred to as the odds ratio can be expressed as

$$
\frac{y}{1-y}
$$

Taking the natural logarithm of the odds ratio gives the log of odds ratio, which can be estimated by the logit method. In the logit model, the log of the odd ratio is a linear function of the explanatory variables:

$$
\log \frac{y}{1-y}=\alpha+\beta 0+\beta 1 \times 1+\cdots+\beta n x n
$$

Where, $\beta=$ coefficients to be estimated, $X=$ explanatory variables. 
Decision to adopt agroforestry practices $(\mathrm{Y})(\mathrm{Yes}=1)$; $(\mathrm{No}=0)$. The adoption decision (dependent function) within the model framework is represented as follows:

$$
Y_{i}=\alpha+\beta_{1} X_{1}+\beta_{2} X_{2} \ldots \ldots \ldots \beta_{n} X_{n}
$$

Where $Y_{i}$ lies between 0 and 1 which is the predicted likelihood of adopting agroforestry practices adopting agroforestry practices is given as $\beta_{1}, \beta_{2}$ $\beta_{\mathrm{n}}$ for a unit increase in the independent variables and $\mathrm{X}(1,2, \ldots \mathrm{n})$ are the independent socio-economic variables. The final model of the decision to adopt agroforestry can therefore be estimated by equation below:

$$
\begin{aligned}
& Y_{1}=\beta_{0}+\beta_{1} X_{1}+\beta_{2} X_{2}+\beta_{3} X_{3}+\beta_{4} X_{4}+\beta_{5} X_{5}+\beta_{6} X_{6}+\beta_{7} X_{7}+\beta_{8} X_{8}+\beta_{9} X_{9} \\
& \beta_{0}=\text { Intercept } \\
& X_{1}=\text { Gender } \\
& X_{2}=\text { Age (in years) } \\
& X_{3}=\text { Household size (No. of persons) } \\
& X_{4}=\text { Educational status (Years spent in school) } \\
& X_{5}=\text { Farm size (in ha.) } \\
& X_{6}=\text { Membership of cooperative society (1= member; } 0, \text { if otherwise) } \\
& X_{7}=\text { Access to extension services ( } 1=\text { yes, } 0, \text { if no) } \\
& X_{8}=\text { Access to credit ( } 1=\text { yes, } 0 \text { if no) } \\
& X_{9}=\text { Farming Experience (in years) } \\
& \beta_{1}-\beta_{9}=\text { Coefficients of the independent variables }
\end{aligned}
$$

\section{RESULTS AND DISCUSSION}

Table 1 shows that $67.74 \%$ of the adopters of agroforestry technology were between 40 and 59 years of age while $69.05 \%$ of non-adopters were within the same age range. About $35 \%$ of the adopters had secondary education while about $39 \%$ of non-adopters had tertiary education. Large proportion $(95.16 \%)$ of the adopters was male while about $82 \%$ of the nonadopters were male, with female accounting for $4.84 \%$ and $17.86 \%$ of the adopters and nonadopters respectively. In addition, majority $(77.42 \%)$ of the adopters had farm size of 8ha and 
Journal of Agriculture and Food Sciences

Volume 19 Number 1, April 2021 pp 189-200

Awe, F., Oguntoye, T.O. and Olatunji, B.T.

below while $85.71 \%$ of the non-adopters had equivalent land holdings. This is an indication that majority of the farm households in the study area are small scale farmers. This is because, according to Ozowa (2005), farm households with less than 10ha of farmland are regarded as small-scale farmers. This is according to international standards measurement for farm sizes. It was also observed that the adopters of agroforestry technology had larger household size than the non-adopters with $67.74 \%$ of the adopters having household size from 6 to 15 while $63.09 \%$ of the non-adopters had same household range. This may not be unconnected to the fact that adopters with larger household sizes realized that they had more people to cater for, hence the need to add tree planting (especially multipurpose and fruit trees) to their farming activities so as to have additional sources of income to cater for family needs.

Table 2 shows the different forms of agroforestry practices adopted by the farmers in the study area. Prominent among the agroforestry practices were boundary planting, life fencing, multipurpose trees/shrubs and wind breaks with $50 \%, 37.10 \%, 35.48 \%$ and $32.26 \%$ of the farmers practicing them respectively. This indicates that agroforestry technologies and different forms of the technology were practiced in the study area, as depicted in Table 2.

\section{Determinants of the adoption of agroforestry technology}

Table 3 shows the results of the analysis to determine the factors that influence the adoption of agroforestry technologies among farmers in the study area. Among the predictors included in the model, only six were found to be significant in determining the adoption of agroforestry technologies among the farmers. The significant variables were access to extension services, age, education level, farming experience, farm size and gender.

It was found from the study that access to extension services had a positive and significant relationship with adoption of agroforestry technologies among farmers in the study area. This indicates that farmers with access to extension services were more likely to adopt agroforestry technologies than farmers without access to extension services. In other words, the odds that a farmer would adopt agroforestry technologies is about eleven times higher with farmers who had access to extension services than those without access to extension services. This is because access to extension education exposes farmers to different farming techniques and systems, including agroforestry information, and as well enhances their adoption decision making. This study therefore corroborates the findings of Adesina et al. (2001) and Basamba et al. (2016) that farmers with higher extension contact are more likely 
to adopt agroforestry technology. Likewise, age of farmer was also positively related to the decision of farmers to adopt agroforestry technologies and statistically significant at 5\% level. This means that older farmers were more willing to adopt agroforestry technologies than younger farmers. This is in agreement with study by Basamba et al. (2016) who stated that age of farmers plays significant role in enhancing the adoption of agroforestry in the Eastern Agro-ecological zone of Uganda.

Furthermore, the positive and significant coefficient on the education level of the farmers implies that educated farmers were more likely to adopt agroforestry technologies than farmers without formal education. In other words, the odds of adoption of agroforestry practices were about twice higher among farmers who had formal education than farmers without formal education. This may not be unconnected to the fact that education improves the understanding of technologies and access to information among the people. It also indicates that education empowers a farmer to make informed decisions and identify farmrelated opportunities where they exist for the benefit of their families.

The study further reveals that farming experience had positive and significantly relationship with farmers' decision to adopt agroforestry technologies in the study area. This is likely so because experienced farmers are more informed about making decisions that affect their farm activities and output. The result shows that farmers with more years of farming were about nine times more likely to adopt agroforestry technologies than farmers with fewer years of farming experience. This is in line with study by Alam (2015) that farmers with more experience of farming are more likely to adopt alternative adaptation strategies. Farm size is also positively and significantly related to adoption of agroforestry technologies, which implies that the larger the farm size, the higher the likelihood of a farmer to adopt agroforestry technologies, since the farmers will have enough land to accommodate both their tree and arable crops for optimal benefits.

In addition, it was discovered that gender of farmer was statistically significant at $5 \%$ level and had a positive relationship with the adoption of agroforestry technology among the farmers. This implies that male farmers were more likely to adopt agroforestry technologies than female farmers. In other words, the odds of adopting agroforestry technologies are about twenty-five times higher among male farmers than female farmers in the study area. That is, male farmers have higher chance of adoption more agroforestry technologies in the study area. In other words, gender is a significant factor determining farmers' level of adoption of 

agroforestry technologies in the study area. This corroborates the findings by Ogada et al. (2010) who discovered that male household heads have a positive relationship in adoption of manure and fertilizer and intensity of their use in Kenya as well as that of Buyinza and Wambede (2008) who attributed the lower agroforestry adoption among women to lack of control over land due to largely patrilineal inheritance systems in Kabale District of Uganda.

\section{CONCLUSION}

It was discovered from the study that adopters of agroforestry technology accounted for $42.47 \%$ of the sampled respondents. The results further reveal those different forms of agroforestry technologies were adopted by the farmers in the study area. These practices include boundary planting, multipurpose trees/shrubs, wind breaks and live fencing. In addition, result of the Logistic Regression showed that socioeconomic attributes of the farmers played significant and positive role in determining farmers' decision to adopt agroforestry technologies or not. 


\section{REFERENCES}

Abimbola, K. (2006). Yoruba Culture: A Philosophical Account. Iroko academic. p. 40. ISBN 978-1-905-3880-04.

Adesina, A. A., Mbila, D., Nkamleu, G. B., Endamana, D. (2001). Econometric analysis of the determinants of adoption of alley farming by farmers in the forest zone of southwest Cameroon. Agric. Ecosys. Environ. 80: 255-265. https://doi.org/10.1016/S01678809(00)00152-3

Alam, K. (2015). Farmers' Adaptation to Water Scarcity in drought-prone Environments: A case study of Rajshahi District, Bangladesh. Agric. Water Mgt., 148: 196-206. https://doi.org/10.1016/j.agwat.2014.10.011

Basamba, T.A., Mayanja, C., Kiiza, B., Nakileza, B., Matsiko, F., Nyende, P. et al. (2016). Enhancing Adoption of Agroforestry in the Eastern Agro-Ecological Zone of Uganda. International Journal of Ecological Science and Environmental Engineering, 3(1): 2031

Buyinza, M. and Wambede, N., (2008). Extension for agroforestry technology adoption: Mixed intercropping of Crotalaria (Crotalaria grahamiana) and Maize (Zea Mays) in Kabale District, Uganda. Environ. Res. Journal, 2 (3):131-137.

Dawson, I.K., Place, F., Torquebiau, E., Malézieux, E., Iiyama, M., Sileshi, G.W et al. (2013). Agroforestry, Food and Nutritional Security. Background Paper for the International Conference on Forest for Food Security and Nutrition. FAO, Rome 13-15 May, 2013.

Franzel, S., Phiri, D., \& Kwesiga, F. (2002). Assessing the adoption potential of improved fallows in eastern Zambia. In S. Franzel \& S. J. Scherr (Eds.), Trees on the Farm: Assessing the adoption potential of Agroforestry Practices in Africa (pp. 37-64). Wallingford, UK, CAB International. https://doi.org/10.1079/9780851995618.0037

Garrity, D. and Stapleton, P. (2011). More trees on farms. Farming Matter, 27(2):8-9.

Kio, P.R.O. (2001). Forestry and Sustainable Agricultural Development. In (Eds) J. J. Owonubi, A. B. Oguntala and M. O. Soladoye. National Workshop on Agriculture and Rural Development in Nigeria, FRIN, Ibadan 14th -16th February, 2000 pp. 34-48.

Odurukwe, S. (2004). Agroforestry in peri-urban cities of Abia State, Nigeria. UM Magazine $8-9$. 
Opio, C. (2001). Biological and Social Feasibility of Sesbania fallow practice in Small Holder Agricultural Farms in Developing Countries: A Zambian Case study. Environmental Management, 27(1), 59-74. https://doi.org/10.1007/s002670010134

Ozowa, B. (2005). Making the Most of Agricultural Investment. www. ifad.org/agri_investment.pdf. Retrieved in November, 2011. 


\section{REFERENCES}

Table 1: Socioeconomic Characteristics of Respondents

\begin{tabular}{|c|c|c|c|c|}
\hline \multirow[b]{2}{*}{ Variable } & \multicolumn{2}{|c|}{ Adopters $(\mathrm{N}=62)$} & \multicolumn{2}{|c|}{ Non-adopters (N=84) } \\
\hline & Frequency & Percentage & Frequency & Percentage \\
\hline \multicolumn{5}{|l|}{ Age (Years) } \\
\hline$\leq 39$ & 02 & 3.23 & 10 & 11.90 \\
\hline $40-49$ & 12 & 19.35 & 25 & 29.76 \\
\hline $50-59$ & 30 & 48.39 & 33 & 39.29 \\
\hline $60-69$ & 13 & 20.97 & 13 & 15.48 \\
\hline$>70$ & 05 & 8.06 & 03 & 3.57 \\
\hline \multicolumn{5}{|l|}{ Gender } \\
\hline Male & 59 & 95.16 & 69 & 82.14 \\
\hline Female & 03 & 4.84 & 15 & 17.86 \\
\hline \multicolumn{5}{|l|}{ Educational Status } \\
\hline No Formal & 02 & 3.23 & 08 & 9.52 \\
\hline Primary & 08 & 12.90 & 10 & 11.90 \\
\hline Secondary & 22 & 35.48 & 29 & 34.52 \\
\hline Tertiary & 21 & 33.87 & 33 & 39.29 \\
\hline Vocational & 09 & 14.52 & 04 & 4.76 \\
\hline \multicolumn{5}{|l|}{ Farm Size (Ha) } \\
\hline$\underline{2}$ & 18 & 29.03 & 22 & 26.19 \\
\hline $2.1-5.0$ & 19 & 30.65 & 40 & 47.62 \\
\hline $5.1-8.0$ & 11 & 17,74 & 10 & 11.90 \\
\hline$\geq 8.1$ & 14 & 22.58 & 12 & 14.29 \\
\hline \multicolumn{5}{|l|}{ Household Size } \\
\hline$\leq 5$ & 18 & 29.03 & 29 & 34.52 \\
\hline $6-10$ & 34 & 54.84 & 50 & 59.52 \\
\hline $11-15$ & 08 & 12.90 & 03 & 3.57 \\
\hline$\geq 16$ & 02 & 3.22 & 02 & 2.38 \\
\hline \multicolumn{5}{|l|}{ Marital Status } \\
\hline Single & 03 & 4.84 & 04 & 4.76 \\
\hline Married & 56 & 90.32 & 73 & 86.90 \\
\hline Widowed & 02 & 3.23 & 05 & 5.95 \\
\hline Divorced/Separated & 01 & 1.61 & 02 & 2.38 \\
\hline \multicolumn{5}{|l|}{ Farming Experience } \\
\hline$\leq 10$ & 05 & 8.06 & 09 & 10.71 \\
\hline $11-20$ & 30 & 48.39 & 40 & 47.62 \\
\hline $21-30$ & 12 & 19.35 & 20 & 23.81 \\
\hline$\geq 31$ & 15 & 24.19 & 15 & 17.86 \\
\hline Access & & & & \\
\hline \multicolumn{5}{|l|}{ Extension } \\
\hline Yes & 39 & 62.90 & 57 & 67.86 \\
\hline No & 23 & 37.10 & 27 & 32.14 \\
\hline
\end{tabular}


Table 2: Agroforestry Technologies Adopted by Respondents ( $N=62)$

\begin{tabular}{lcl}
\hline Agroforestry Technology & *No of Respondents & Percentage \\
\hline Taungya & 6 & 9.68 \\
Home Gardens & 15 & 24.19 \\
Multipurpose Trees/Shrubs & 22 & 35.48 \\
Life Fencing & 23 & 37.10 \\
Boundary Planting & 31 & 50.00 \\
Wind Breaks & 20 & 32.26 \\
\hline
\end{tabular}

Source: Field Survey, $2019 *$ Multiple responses

Table 3: Determinants of the Adoption of Agroforestry Technologies

\begin{tabular}{lccc}
\hline Variable & Coefficient & Odd Ratio & p-value \\
\hline Gender & 3.203 & 24.606 & $0.020^{*}$ \\
Age & 2.331 & 10.288 & $0.014^{*}$ \\
Household size & 2.032 & 7.629 & 0.123 \\
Educational status & 0.633 & 1.883 & $0.017^{*}$ \\
Farm size & 1.734 & 5.663 & $0.001^{*}$ \\
Cooperative membership & 1.342 & 3.827 & 0.379 \\
Extension services & 2.431 & 11.370 & $0.036^{*}$ \\
Credit facilities & 2.411 & 11.145 & 0.340 \\
Farming experience & 2.233 & 9.328 & $0.042^{*}$ \\
\hline
\end{tabular}

Source: Field Survey, 2019 